\title{
The PT at 35: Revisiting Scholarly Interpretations of the Brazilian Workers' Party
}

\author{
OSWALDO E. DO AMARAL* and TIMOTHY J. POWER
}

Abstract. This review essay critically examines the evolution of scholarly literature on Brazil's Partido dos Trabalhadores since the PT's founding in I980. We periodise the relevant literature into four phases, examining the foundation of the PT, the party's early experience in subnational government, its transformation and moderation in the late I990s, and finally its experiences in national government since capturing the presidency in 2002. After detailing strengths and weaknesses of this research, we also examine the trajectory of the PT in light of recent comparative work on the so-called 'left turn' in Latin America. We conclude by offering an agenda for future research on the PT.

Keywords: Brazil, PT, Worker's Party, Lula

On 6 February 201 5, the Brazilian Workers' Party (PT) celebrated its thirtyfifth anniversary at the Minascentro convention centre in Belo Horizonte. The rapturous delegates were treated to a video montage of the party's history plus a speech by the guest of honour, President José 'Pepe' Mujica of Uruguay, who spoke movingly of the PT's importance to the Latin American Left. Even more impressive was the Brazilian political firepower on display amidst a sea of red flags in the packed I,700-seat theatre. On the stage, the impossibly wide mesa de honra included six serving cabinet ministers, five sitting state governors, and of course two presidents of Brazil, Luiz Inácio Lula da Silva (2003-10) and Dilma Rousseff (201 I-present). The pomp and circumstance

Oswaldo E. do Amaral is an assistant professor of political science at Unicamp. Email: oswamaral@gmail.com. Timothy J. Power is an associate professor of Brazilian studies at the University of Oxford. Email: timothy.power@lac.ox.ac.uk.

* This commentary originated in a workshop entitled 'The PT from Lula to Dilma: Understanding Changes in the Brazilian Workers' Party' held by the Brazilian Studies Programme, University of Oxford, in January 20 I 2. The authors are grateful to the workshop participants for their comments. The authors would also like to thank the JLAS reviewers for their valuable comments and suggestions. 
stood in sharp contrast to the PT's humble founding in 1980 in a small, drab auditorium in the Colégio Sion, a secondary school in São Paulo. In its 35 years of existence the Workers' Party had become the most firmly established political party in Brazil and the most important leftist party in Latin America. The PT's story is one of extraordinary institutional success in a political system wherein parties typically have shallow roots in society.

The PT's unique history has made it the most studied of the political parties that emerged or were reorganised in the wake of the Brazilian military regime (1964-85). Dissertations, theses, books, and articles, both in Brazil and abroad, have sought to explain the party from diverse theoretical and methodological vantage points. The topics discussed in these studies have included the party's origin and formation, ideological transformations, organisational support base, relations with civil society, and governing experience at both the subnational and federal levels. Indeed, it would not be an overstatement to speak of a 'PTology', or a sub-area within studies of political parties and the party system in Brazil dedicated solely to the study of the PT. ${ }^{\mathrm{I}}$

The goal of this article is to provide a critical overview of the scholarly literature on the Workers' Party. In doing so, we illustrate how the research agenda on the party, as well as the methods used to analyse it, have developed alongside the PT itself over the past 35 years. We also demonstrate that due to the central role played by the PT in the Brazilian political system, analyses of the party shed light on the development and consolidation of democracy in Brazil during the past three decades. To that end, we have organised this article into three sections. In the first section, we discuss the literature on the party by categorising it according to four different themes or 'waves' of study. We identify distinct waves of scholarly analysis on ( $\mathrm{I}$ ) the formation and consolidation of the PT, (2) the party's early experiences in subnational government, (3) the subsequent transformation and moderation of the PT, and finally (4) the PT in federal government since 2003. In the second section, we explore the lessons offered by the literature on the PT and assess the extent to which studies of the PT have advanced broader understandings of Brazilian politics and of the trajectories of leftist parties across Latin America. In the third and final section, we identify remaining lacunae in the literature and propose an agenda for future research.

\section{Waves of Study of the PT}

To begin, we evaluate the literature produced on the PT by categorising it according to four different themes, or waves, that have emerged in the

${ }^{1}$ The expression PTologia was suggested by Maria Hermínia Tavares de Almeida during the workshop 'The PT from Lula to Dilma: Understanding Changes in the Brazilian Workers' Party', organised by the authors as part of the Brazilian Studies Programme of the University of Oxford in January $20 \mathrm{I} 2$. 
literature. Before proceeding, two caveats bear mentioning. First, as with any broad categorisation, there is a necessary degree of oversimplification in the discussion that follows. Our periodisation obscures the fact that many of the studies mentioned here contain material that extends beyond the categories used below. Second, there is a notable correspondence between the themes identified here and the periods in which the work under discussion was produced. Naturally, this reflects the different historical phases that the PT has passed through and its development over its first 35 years as a party.

\section{Wave I: founding and consolidation of the PT}

In her introduction to The Workers' Party and Democratisation in Brazil, published in 1992, Margaret Keck prefaced her study by noting the following:

This [book] is the study of an anomaly. Unlike other political parties created in the I 980 os, the Workers' Party had a solid base in labor and social movements, took seriously the question of representation (both in internal organisation and with regard to electoral constituencies), and couched its appeal in programmatic terms. The PT and the central union organisation with which it is organically (although not institutionally or juridically) linked, the Central Única dos Trabalhadores (CUT), are the most coherent and institutionalised new political actors to emerge during the Brazilian transition. ${ }^{2}$

This excerpt is representative of the central arguments made in studies of the origin and early years of the Workers' Party, which typically refer to the party as a novelty and an exception in Brazilian politics, a novelty due to the process by which the party formed, its political proposals, and its internal organisation; an exception because of the high levels of cohesion and discipline achieved by the party despite a context of weak, poorly institutionalised, catch-all parties. Among these studies, two stand out for their breadth and theoretical consistency: those produced by Meneguello and Keck. ${ }^{3}$ Both are considered landmark texts on the PT, and they pioneered an interpretation of the origins and first years of the party that remains prominent to this day. It is difficult to find any serious study of the PT that fails to cite these two early contributions. While they differ slightly in focus and level of detail, both books highlight the uniqueness of the PT's bottom-up formation guided by a confluence of diverse social actors. In the early i 980 s, unionists, members of the organised Left, and progressive sectors of the Catholic Church and urban social movements, as well as intellectual and politicians from the Brazilian Democratic Movement (MDB), embraced the creation of the PT and contributed to the 'DNA' of the party.

${ }^{2}$ Margaret E. Keck, The Workers' Party and Democratization in Brazil (New Haven, CT: Yale University Press, I 992), p. 3.

${ }^{3}$ Rachel Meneguello, PT: a formação de um partido, 1979-1982 (São Paulo: Paz e Terra, I 992); Keck, The Workers' Party and Democratization in Brazil. 
In addition to highlighting the PT's 'outsider' origins, both Keck and Meneguello document the party's interest in designing internal democratic institutions that would encourage the participation of the party's rank-andfile in collective decision-making. Meneguello places more emphasis on grassroots organisations (núcleos de base) and their role in the party-building process. ${ }^{4} \mathrm{Keck}^{5}$ demonstrates how the party was concerned with representing and responding to its electoral constituencies. ${ }^{6}$ Both scholars delineate the programmatic profile of the party and the heterogeneous sources from which it emerged. Meneguello also emphasises the party's tactic of describing itself as both social-democratic and communist, which resulted in somewhat imprecise policy proposals: the party advocated an amorphous 'democratic socialism'.

Drawing on Duverger's classic typology,7 Meneguello argued that the PT was the first mass party to emerge in Brazilian history. In making this claim, she cited not only the bottom-up, extra-parliamentary genesis of the PT, but also its strong ties to organised social forces, its centralised model of internal operations, intense internal activity, and the primacy it placed on aggregating interests rather than accumulating electoral victories. The mass-party interpretation was echoed in many other subsequent studies of PT party organisation, including those authored by Mainwaring, Samuels, Hunter and Ribeiro, to mention only a few. ${ }^{8}$

The influence of Meneguello and Keck has been enduring, but other studies have also contributed to our understanding of the characteristics of and challenges faced by the PT in its early years. Gadotti and Pereira analyse documents marking the foundation of the party and explore the tensions caused by its entrance into the political arena. 9 Oliveira also offers a rich panorama of the transformations wrought by the New Unionism and its construction of a broader, more inclusive political agenda in the period immediately prior to the PT's founding. ${ }^{\circ}$ Azevedo conducts an analysis of the ideological position adopted by the party, paying particular attention to the party's conceptions of

${ }^{4}$ Meneguello, ibid.

s Keck, ibid.

${ }^{6}$ Keck, ibid.

${ }^{7}$ Maurice Duverger, Political Parties: Their Organisation and Activity in the Modern State (New York: Wiley, 1954).

${ }^{8}$ Scott Mainwaring, Rethinking Party Systems in the Third Wave of Democratisation: The Case of Brazil (Stanford, CA: Stanford University Press, 1999); David Samuels, 'From Socialism to Social Democracy: Party Organisation and the Transformation of the Workers' Party in Brazil', Comparative Political Studies, 37: 9 (2004), pp. 999-1024; Wendy Hunter, The Transformation of the Workers' Party in Brazil, 1989-2009 (Cambridge: Cambridge University Press, 2010); Pedro Ribeiro, Dos sindicatos ao governo: a organização nacional do PT de Ig8o a 2005 (São Carlos: Editora UFSCar, 2010).

9 Moacir Gadotti and Otaviano Pereira, Pra que PT? Origem, projeto e consolidação do Partido dos Trabalhadores (São Paulo: Editora Cortez, I989).

10 Isabel R. de Oliveira, Trabalho e politica: as origens do Partido dos Trabalhadores (Petrópolis: Vozes, I987). 
socialism and democracy, and concluding that the PT, in its early years, adopted an ambiguous rhetoric marked by a tension between Leninist and social-democratic paradigms. ${ }^{11}$ In addition, Azevedo makes an effort to categorise the ideological positions of the various groupings that were distinctively visible in the party until the mid-r990s.

Finally, the works of Lacerda, Roma and Leal focus on the development of party rules and their impact on party members and representatives. ${ }^{12}$ Lacerda analyses both the divergences among the PT's groups and the impact of internal rules over the party unity. The author advances a classification of ideological positioning of internal factions on the left-right continuum and argues that the democratic intra-partisan institutional design has discouraged splits throughout the PT's history. According to Lacerda, it was better for minority factions to stay and have the opportunity to influence some internal decisions than to form another small leftist party without electoral support or representatives. Roma analyses the development of the PT's foundational organisational structures by comparing them with those of the PSDB. His research demonstrates how the origins and the ideology of both parties helped to shape their institutional designs. Being composed by a series of different ideological groups and factions and with strong roots in civil society, the PT had to develop an organisation in which all groups could participate in the decision-making process and the leaders were held accountable by rank-and-file. On the other hand, the PSDB (founded in 1988) was formed by existing political elites inside the National Congress, and its leaders demanded a more flexible organisation through which they could accommodate their personal and regional interests. Leal accounts for how the PT's representatives in the Chamber of Deputies deal with the dilemma of pursuing electoral success despite the strong legislative whip imposed by party leaders. The strategic answer, according to him, relies on the close relationship between PT deputies and social movements.

Despite the considerable literature on the formation of the PT, some questions remain unaddressed. One such question is related to the impact of interregional differences in the process of party formation. Because Keck and Meneguello were concerned with the initial founding of the PT, they naturally focused their attention on the state of São Paulo. ${ }^{13}$ However, as Keck notes, the party experienced different growth trajectories in other states. ${ }^{14}$ In spite of good monographic studies of the emergence of the PT in different states

${ }^{11}$ Clóvis Bueno Azevedo, A estrela partida ao meio (São Paulo: Editora Entrelinhas, 1995).

12 Alan Daniel Lacerda, 'O PT e a unidade partidária como problema', Dados, 45: i (2002), pp. 39-76; Celso Roma, 'Organizaciones de partidos en Brasil: el PT y el PSDB bajo perspectiva comparada', América Latina Hoy, 44 (2006), pp. I 53-84; Paulo Roberto Figueira Leal, $O$ $P T$ e o dilema da representação politica (Rio de Janeiro: Editora FGV, 2005).

${ }^{13}$ Keck, The Workers' Party and Democratization in Brazil ; Meneguello, PT: a formação de um partido, 1979-1982.

${ }^{14}$ Keck, The Workers' Party and Democratization in Brazil, pp. 98-103. 
and municipalities, such as Petit's ${ }^{15}$ analysis of the PT's trajectory in Pará and Braga's ${ }^{16}$ study of how the differing contexts of São Paulo and Rio de Janeiro influenced the nature of the PT in those localities, we still know little about the role that distinct regional processes of party formation played in shaping the organisational development of the Worker's Party, especially in comparative perspective.

\section{Wave 2: subnational experiences}

Alongside the greater institutional insertion of the PT in the executive and legislative spheres in the 1980 s and I990s, newer works began to analyse the challenges posed by those new environments and how the party engaged in the development of public policy. Studies by Simões and Couto are among those that highlight the dilemmas and difficulties posed by the party's new status as a 'governing party'. ${ }^{17}$ Analysing the PT's stint in the city government of São Paulo between 1989 and I992, Couto shows how that experience was critical to solidifying the PT's view that governing requires both policy flexibility and broad-based political alliances. Two decades later, it is interesting to note that many of the dilemmas encountered by the party in São Paulo and identified by Couto ultimately reappeared on a larger scale during Lula's government, when the PT rank-and-file once again debated the utility of pragmatism. Couto provides a fine-grained analysis of the challenges faced by the administration of São Paulo Mayor Luiza Erundina (elected with less than 30 per cent of the vote in 1988$)^{18}$ in garnering support for bills over the resistance of groups within the PT and in the absence of a stable governing coalition in the municipal legislature. Problems associated with the distribution of posts in the São Paulo municipality, both among members of different PT groups and among political allies, contributed to the conflictual relationship that emerged between the Prefeitura and its modest support base on the city council. ${ }^{19}$

The rise in the number of municipalities administered by the PT, the election of successive PT governments in the city of Porto Alegre, and the emergence of

${ }^{15}$ Pere Petit, A esperança equilibrista: a trajetória do PT no Pará (São Paulo: Boitempo, 1996).

${ }^{16}$ Maria do Socorro Sousa Braga, 'Partido dos Trabalhadores: condições de origem e variaçooes estaduais', in Vítor Amorim de Angelo and Marco Antônio Villa (eds.), O Partido dos Trabalhadores e a politica brasileira (1980-2006): uma história revisitada (São Carlos: Editora UFSCar, 2009).

${ }^{17}$ Júlio Simões, $O$ dilema da participação popular: a etnografia de um caso (São Paulo: Marco Zero, 1992); Cláudio Couto, O desafio de ser governo: o PT na prefeitura de São Paulo (I989-I992) (Rio de Janeiro: Paz e Terra, 1995).

${ }^{18}$ Brazilian municipalities with more than 200,000 voters now use runoff elections, but this rule did not apply in 1988. If she had faced a second round ballot, Erundina would almost certainly have been defeated by former mayor and governor Paulo Maluf, a loyal ally of the military regime who returned to the mayoralty in 1992 .

19 Couto, $O$ desafio de ser governo. 
PT-led state governments across Brazil resulted in a large number of studies analysing not only participatory budgeting (PB) but also a wider array of innovative practices, collectively referred to as the 'PT way of governing' (o modo petista de governar). This literature can be divided into two categories. The first was produced by the party itself, or by PT leaders, with the goal of systematising and promulgating public policies that were branded by the party as the 'inversion of investment priorities' (inversão de prioridades) and 'popular participation' (participação popular). Good examples of work in this category include Genro and Souza on the experience of PB in Porto Alegre and studies organised by Barreto, Magalhães and Trevas and by Bittar on public policies developed at the municipal and state levels, respectively. ${ }^{20}$ These texts played an important role in convincing both academics and policy-makers that PT governments were capable of novel administrative solutions that were faithful to the history and tradition of the party. As a result, they helped to consolidate a public image of the party as being fundamentally different from its competitors. Yet one clear shortcoming of these studies is the frequent absence of a critical perspective on the programmes and projects developed by the PT across Brazil. Several of the texts in question simply parrot the official rhetoric of the party or the administration being analysed.

The second category is made up of more academically oriented studies that provide theoretical and practical assessments of the success of participatory budgeting under a variety of PT administrations. Both in Brazil and abroad, books and articles have discussed the practices established by PB with an eye to the construction of new dynamics of democratic mobilisation. Studies organised by Avritzer and Navarro and by Baiocchi are among the most influential in this vein. ${ }^{21}$ They attempt not only to describe and categorise various experiences with PB but also to explain the different levels of success achieved by PB in different contexts.

In spite of important advances in the literature on the PT's participatory practices, there is still a gap in our understanding of the variables driving differing outcomes in the development of $\mathrm{PB}$ in different localities. Few studies, for example, have sought to investigate the relationship between the degree of party organisation, the trajectory of party institutionalisation or the social composition of PT constituencies and the concrete participatory

20 Tarso Genro and Ubiratan Souza, Orçamento participativo: a experiência de Porto Alegre (São Paulo: Fundação Perseu Abramo, 200I); Luiz Barreto, Inês Magalhães and Vicente Trevas (eds.), Governo e cidadania: balanço e reflexóes sobre o modo petista de governar (São Paulo: Fundação Perseu Abramo, 1999); Jorge Bittar (ed.), Governos estaduais: desafios e avanços (São Paulo: Fundação Perseu Abramo, 2003).

${ }^{21}$ Leonardo Avritzer and Zander Navarro (eds.), A inovação democrática no Brasil: o orçamento participativo (São Paulo: Editora Cortez, 2003); Gianpaolo Baiocchi, Radicals in Power: The Workers' Party (PT) and Experiments in Urban Democracy in Brazil (London: Zed Books, 2003). 
practices developed in various local contexts. A partial exception is the important contribution by Wampler, which is not a study of the Workers' Party per se but which uses a comparative research design to investigate $\mathrm{PB}$ outcomes in eight Brazilian cities. ${ }^{22}$

\section{Wave 3: the transformation and moderation of the PT}

Lula's victory in the 2002 presidential elections was accompanied by a spate of new contributions attempting to explain how the party had changed in the second half of the I990s. Prior to these efforts, work by Novaes, Rodrigues and Singer had already identified important shifts not only in the party's programme and organisation, but also in the profile of the party's leadership. ${ }^{23}$ Novaes points to the greater institutional incorporation of party militants and to the bureaucratisation of the PT as factors that reduced its transformative capacity. Rodrigues shows how the profile of the party's leadership changed during the $1980 \mathrm{~s}$, incorporating greater numbers of professionals, public-sector employees, and professors, that is, salaried, urban workers from the middle class. Focusing on these newer white-collar constituencies within the PT family, Rodrigues questions whether the party would be able to maintain its programmatic rhetoric and internal cohesion in the face of the inevitable pressures arising from the greater insertion of the PT into mainstream institutional politics. Singer, in the first work to attempt a systematic history of the PT, identifies similarities between the PT and European social democracy. He argues that in both cases greater participation in the institutional arena and a desire to win elections inevitably led parties down a path of ideological moderation. Though his analysis is impressionistic at times, Singer foreshadows many of the strategic debates that subsequently emerged during the Lula government.

In the past decade, some of the broad questions raised by these studies have inspired more empirically grounded work that seeks to establish the extent to which the PT actually underwent ideological, programmatic, and organisational change. This literature suggests that the party moved towards the centre of the political spectrum, that its political programme became less ideological, that compromises were made with representative democracy, and that the PT began to place greater emphasis on its electoral competitiveness by

${ }^{22}$ Brian Wampler, Participatory Budgeting in Brazil: Contestation, Cooperation, and Accountability (College Park, PA: Penn State University Press, 2007).

${ }^{23}$ Carlos Alberto Marques Novaes, 'PT: dilemas da burocratização', Novos Estudos Cebrap, 35 (1993), pp. 217-37; Leôncio Martins Rodrigues, 'PT: A New Actor in Brazilian Politics', in Fernando J. Devoto and Torcuato S. Di Tella (eds.), Political Culture, Social Movements and Democratic Transitions in South America in the 2oth Century (Milan: Feltrinelli, 1997); André Singer, O PT (São Paulo: Publifolha, 200I). 
professionalising its party structure and granting its leadership more autonomy with relation to the party base.

While there is a reasonable consensus in the literature with respect to the changes undergone by the PT, there is little agreement about what caused them and about how the PT case fits into a broader theoretical account of comparative political parties. Work by Ribeiro revolves around two dimensions of analysis: functional and organisational. ${ }^{24} \mathrm{He}$ suggests that the PT followed the European social-democratic path, acquiring the characteristics of an 'electoral-professional party' as defined by Panebianco ${ }^{25}$ and becoming more and more dependent on the state, thus also resembling the 'cartel party' model proposed by Katz and Mair. ${ }^{26}$ Based on a clear theoretical framework and a strong empirical execution, Ribeiro relies heavily on the voluminous literature on Western European social democracy. This emphasis on European parallels, however, has the effect of obscuring certain specificities of the PT case - particularly the party's strong tendency to retain practices and rules that have shaped its organisational development. In contrast, work by Amaral on the transformation of the PT highlights the singularity of the PT experience. ${ }^{27}$ Amaral seeks to reassess the transformations experienced by the PT in recent decades, showing that changes in the internal organisation of the PT attempt to reconcile aspects of the party's origins and trajectory with the newfound necessity of winning elections and exercising power.

Though they diverge in some respects, the work of both Ribeiro and Amaral demonstrates how the construction of a new 'dominant coalition' around a moderate group called the 'Majority Faction' (Campo Majoritário), whose leadership included José Dirceu and Lula himself, was fundamental to the process of the party's transformation. Both scholars agree that the Majority Faction, which controlled the party's national executive between i995 and 2005, spearheaded a series of changes that definitively altered the PT. These include not only the obvious ideological moderation of the party, but also the tireless construction of a party machine that had national scope and that was considerably more efficient from an electoral standpoint. ${ }^{28}$

${ }^{24}$ Ribeiro, Dos sindicatos ao governo.

${ }^{25}$ Angelo Panebianco, Modelos de partido: organização e poder nos partidos politicos (São Paulo: Martins Fontes, 2005).

${ }^{26}$ Richard Katz and Peter Mair, 'Changing Models of Party Organisation and Party Democracy: The Emergence of the Cartel Party', Party Politics, I: I (1995), pp. 5-28; 'The Cartel Party Thesis: A Restatement', Perspectives on Politics, 7: 4 (2009), pp. 753-66.

${ }^{27}$ Oswaldo E. do Amaral, 'Ainda conectado: o PT e seus vínculos com a sociedade', Opinião Pública, 17: I (2011), pp. I-44; 'As transformações nas formas de militância no interior do PT: maior inclusão e menor intensidade', Revista Brasileira de Ciências Sociais, 28: 82 (2013), pp. 67-86.

${ }^{28}$ Ribeiro, Dos sindicatos ao governo; Amaral, 'Ainda conectado'; Amaral, 'As transformações nas formas de militância'. 
The works of Silva and Coelho also present interesting narratives about intra-party change and the ideological moderation of PT notables. ${ }^{29}$ Reviving a hypothesis first advanced by Novaes, ${ }^{30}$ Silva claims that the decision to invest in electoral competition led to creeping bureaucratisation within the PT. This, in turn, led to the emergence of particularistic demands by both leaders and militants, such as the efforts of activists to keep their jobs in the state apparatus. Coelho, adopting a Gramscian approach, dissects the two tendencies that formed the 'Majority Faction' (Articulação and Democracia Radical) in the I990s. Focusing on ideological change within these groups between 1978 and 1998, the author claims that an initial Marxist orientation was gradually supplanted by postmodern and liberal influences. Coelho claims that these changes reflect a classic form of trasformismo, in which both groups adapted their Weltanschaunng in the broad context of the global crisis of Marxism.

Studies by Samuels and Hunter, the most influential English-language contributions in this vein, offer divergent analyses of the PT's evolution during its opposition to the presidency of Fernando Henrique Cardoso (PSDB, I9952002). ${ }^{31}$ However, it is possible to treat their contributions as complementary, since both recognise the importance of endogenous and exogenous factors in explaining changes in the PT. Samuels emphasises internal aspects of the party as key to understanding those transformations, and shows that the increasingly pragmatic outlook of PT leaders and militants nudged it down a path of ideological moderation beginning in the second half of the 1990s. For Samuels, the number of pragmatically-minded party militants grew in the 1990 s because of the governing experiences of the PT at the subnational level and because of moderation in strategy and objectives on the part of the unions and social movements that were core constituencies of the party. These changes within the grassroots base, reflected in the PT rules of internal democracy, gave the party's leaders the flexibility they needed to steer the party towards a more centrist ideological position. In contrast, Hunter ascribes more weight to external factors as the principal causes of party change, drawing theoretical insights from both rational choice institutionalism and historical institutionalism. In her view, the global economic setting during the I990s made it practically

29 Antonio Ozaí Silva, 'Nem reforma nem revolução: a estrela é branca', in Vítor Amorim de Angelo and Marco Antônio Villa (eds.), O Partido dos Trabalhadores e a politica brasileira (I980-2006): uma história revisitada (São Carlos: EdUFSCar, 2009); Eurelino Coelho, 'Uma esquerda para o capital: crise do Marxismo e mudanças nos projetos políticos dos grupos dirigentes do PT (1979-1998)', unpubl. PhD diss., Universidade Federal Fluminense, Brazil, 2005.

30 Novaes, 'PT: dilemas da burocratização'.

${ }^{31}$ Samuels, 'From Socialism to Social Democracy: Party Organization and the Transformation of the Workers' Party in Brazil'; Wendy Hunter, 'The Normalization of an Anomaly: The Workers' Party in Brazil', World Politics, 59 (2007), pp. 440-75; Hunter, The Transformation of the Workers' Party in Brazil, 1989-2009. 
impossible to achieve electoral competitiveness while maintaining an antimarket ideological stance. Furthermore, a political environment consisting of floating voters and a fragmented party system furnished the PT with a strong incentive to moderate its positions in order to finally win a presidential election. Hunter recognises, however, that the PT retains some of its congenital characteristics, most notably the continued uneasy coexistence of ideologically distinct groups with a centralised national bureaucratic structure.

\section{Wave 4: the PT in the federal government}

The literature on the PT's time in the federal government, where it has controlled the presidency since I January 2003, remains closely linked to discussions of the changes undergone by the party. However, the party's unique position on the Brazilian political stage, and its acquisition of control of the federal executive for the first time, have meant that some scholars have sought to understand the effects of incumbency both on governing style (o modo petista de governar) and on intra-party tensions. Before proceeding, we also note that at present, the published literature on the PT in national government overwhelmingly covers the Lula years $(2003-10)$ rather than the period since the accession of Dilma Rousseff in January 20 I I.

Hochstetler analyses the relationships among the Lula government, the PT and organised civil society between 2003 and 2006.32 In her view, organised civil society and the PT grew apart during Lula's first government, ending the near-monopoly the party had enjoyed on the political representation of progressive social movements. That distancing was caused by Lula's continuation of economic policies implemented by the FHC government, and by organised civil society's disappointment in the limited extent to which civil society organisations (CSOs) were able to participate in the Lula administration. Hochstetler's excellent analysis concentrates on the policy initiatives of the PT in the federal government, and therefore does not provide a detailed micro-level accounting of the level of participation of organised civil society within the PT, which might in turn give a better sense of the true extent to which relations between the party and social movements became frayed. Baiocchi and Checa argue along similar lines that the principal change in the PT while in power was not a 'movement toward the center' of the ideological spectrum nor the adoption of economic policies considered orthodox, but the jettisoning of a signature PT project: the construction of new

${ }^{32}$ Kathryn Hochstetler, 'Organized Civil Society in Lula's Brazil', in Peter Kingstone and Timothy J. Power (eds.), Democratic Brazil Revisited (Pittsburgh, PA: University of Pittsburgh Press, 2008). 
democratic practices. ${ }^{33}$ Pogrebinschi and Santos, in an analysis that covers the entirety of the Lula years, present a different interpretation. ${ }^{34}$ In their view, Lula innovated by making the National Conferences of Public Policy, instruments that involve the participation of civil society in the elaboration of guidelines for the formulation of public policy at the federal level, more comprehensive, wide-ranging, inclusive and frequent. According to Pogrebinschi and Santos, it was also after 2003 that the conferences acquired their deliberative, normative and representative character. That interpretation is strongly endorsed by Avritzer, who evaluates the participatory mechanisms created in post-authoritarian Brazil and concludes that Lula's governments institutionalised the convening of regular conferences on topics linked to social policy, especially during his second term (2007-10).35

Although some of the scholars cited in Wave 2 above had expressed concern that the PT might not be able to 'federalise' some of the participatory practices innovated at the subnational level, both Pogrebinschi and Santos and Avritzer clearly suggest that PT governments proved capable of implementing new forms of participation and formulation of public policy in Brazilian democracy. However, further research is needed to evaluate the causal impact of those new practices on legislative production and the elaboration of specific programmes by the executive.

Hunter and Samuels examine the 'PT way of governing' to evaluate PT performance in the federal government under Lula. ${ }^{6}$ For Hunter, the PT government did not prove capable of upholding many of the principles that it had historically defended, especially those of popular participation (participação popular) and ethics in politics (ética na politica). Hunter argues that the mensalão scandal of 2005 destroyed the PT's image as immune to corruption, which had been central to the construction of the PT brand in the I990s. She recognises, however, that the PT did succeed in fulfilling some of its historical promises by expanding social programmes and public policies that helped to reduce poverty. Samuels reaches a slightly different conclusion. Like

33 Gianpaolo Baiocchi and Sofia Checa, 'The Brazilian Workers' Party: From Local Practices to National Power', Journal of Labor and Society, Io: 4 (2007), pp. 4 I I-30.

34 Thamy Pogrebinschi and Fabiano Santos, 'Participação como representação: o impacto das Conferências Nacionais de Políticas Públicas no Congresso Nacional', Dados, 54: 3 (20 I I), pp. 259-305.

35 Leonardo Avritzer, 'Living under a Democracy: Participation and its Impact on the Living Conditions of the Poor', Latin American Research Review, 45 (special issue) (2010), pp. 166-85.

36 Wendy Hunter, 'Brazil: The PT in Power', in Steven Levitsky and Kenneth Roberts (eds.), The Resurgence of the Latin American Left (Baltimore, MD: Johns Hopkins University Press, 20II); David Samuels, 'Brazilian Democracy in the PT Era', in Jorge Domínguez and Michael Shifter (eds.), Constructing Democratic Governance in Latin America (4th edition) (Baltimore, MD: Johns Hopkins University Press, 2013). 
Pogrebinschi and Santos and Avritzer, ${ }^{37}$ he suggests that the PT managed to expand the participation of organised civil society in the formulation of public policy. Moreover, the PT government managed to achieve both economic growth and poverty reduction, which, in Samuels' view, helped to cement the idea that the party represented all Brazilians. This, in turn, cemented the party's hold on a substantial portion of the electorate.

The major failure of the PT governments according to Samuels was the frequency and magnitude of corruption scandals that were linked to the Lula administration. ${ }^{38}$ Samuels establishes an important link between, on the one hand, the natural difficulty of building majorities in any presidential regime with high party fragmentation and, on the other hand, the nature of the PT as a strongly institutionalised party with sharp internal divisions. Unlike other political parties that occupied the presidency in the post-1985 period, the PT had to overcome both inter-party and intra-party tensions. Differently from his predecessor Cardoso, Lula needed to satisfy not only his support base in Congress but also his co-partisans. The connection between corruption scandals and the difficulty of governing under a dynamic of 'coalitional presidentialism' is also addressed by Flynn, Palermo, Amorim Neto, Goldfrank and Wampler and, especially, Pereira, Power and Raile. ${ }^{39}$ According to these scholars, one of the factors that precipitated a political crisis in 2005 was the PT's insistence on occupying a disproportionate number of ministries and posts, leading to the construction of an imbalanced cabinet as compared to the governing base in the legislature. However indirectly, these analyses suggest the importance of the internal organisation of political parties as an explanatory variable in understanding the formation of governing coalitions. Unfortunately, internal organisation is often neglected by the literature.

Another set of analyses produced since Lula's first victory tries to explain the changes in the PT's support base at the mass level. As the PT has consolidated its position as the party with the most partisan identifiers in Brazil, a

37 Pogrebinschi and Santos, 'Participação como representação: o impacto das Conferências Nacionais de Políticas Públicas no Congresso Nacional'; Avritzer, 'Living under a Democracy: Participation and its Impact on the Living Conditions of the Poor'.

${ }^{38}$ Samuels, 'Brazilian Democracy in the PT Era'.

39 Peter Flynn, 'Brazil and Lula, 2005: Crisis, Corruption and Change in Political Perspective', Third World Quarterly, 26: 8 (2005), pp. I 22 I-67; Vicente Palermo, 'Brasil: el gobierno de Lula y el PT', Nueva Sociedad, I92 (2005), pp. 4-1 I; Octavio Amorim Neto, 'Algumas consequências políticas de Lula: novos padrões de formação e recrutamento ministerial, controle de agenda e produção legislativa', in Jairo Nicolau and Timothy J. Power (eds.), Instituições representativas no Brasil: balanço e reforma (Belo Horizonte: Editora UFMG, 2007); Benjamin Goldfrank and Brian Wampler, 'From Petista Way to Brazilian Way: How the PT Changes in the Road', Revista Debates, 2: 2 (2008), pp. 245-71; Carlos Pereira, Timothy J. Power and Eric D. Raile, 'Presidentialism, Coalitions, and Accountability', in Timothy J. Power and Matthew M. Taylor (eds.), Corruption and Democracy in Brazil: The Struggle for Accountability (Notre Dame, IN: University of Notre Dame Press, 201 I), pp. 3 I-55. 
series of studies has sought to understand who the petistas (PT supporters) are, and how their composition has changed during the party's time in the Planalto Palace. According to Veiga, Samuels, Venturi and Singer, the PT has undergone a process of territorial nationalisation since the $1990{ }^{4}{ }^{4}$ This has led to a corresponding reduction in the proportion of its supporters who reside in Brazil's southeast, the birthplace of the party. The most interesting findings, however, lie in analyses of changes that took place during the Lula government. For Veiga, Venturi and Singer, the PT under Lula was successful in making new inroads into constituencies with low incomes and limited education. Samuels, for his part, is more cautious in discussing changes in the petista profile under Lula. He argues that the typical PT identifier continues to live in developed urban centres, participate actively in politics, and be better politically informed than the majority of Brazilians. Samuels also notes, however, that left-right ideology is no longer a reliable predictor of PT affiliation, suggesting a moderation in the beliefs of party supporters.

The interesting discoveries offered by these studies have yet to be accompanied by broader accounts of party system change in Brazil. Many questions were raised. Has the success of the Lula governments' policies with regard to particular social segments exerted an effect on levels of support for the PT? Do these data reflect a realignment in Brazilian politics? Who are the ex-petistas and the new petistas? New studies and surveys are still needed in order to achieve a clearer understanding of changes in the PT's support base and their consequences for Brazilian politics.

Recent analyses presenting comprehensive and engaging interpretations of the PT's years in the Planalto Palace include those of Anderson, Secco, Bruera and Singer ${ }^{41}$ Anderson's vivid essay is an excellent introduction for non-specialists seeking to understand what the rise of Lula and the PT has meant for Brazilian macro-politics. Anderson claims that while the Lula government maintained the economic policies that it inherited from the Cardoso government, nonetheless, the PT-led coalition succeeded in reorienting the state towards policies that benefited the poorest Brazilians. Anderson is cognizant of the fact that the Lula government's success lay precisely in its ability to improve the lives of the poorest while simultaneously preserving a profoundly

${ }^{40}$ Luciana Veiga, 'Os partidos brasileiros na perspectiva dos eleitores: mudanças e continuidades na identificação partidária e na avaliação das principais legendas após 2002', Opinião Pública, I 3: 2 (2007), pp. 340-65; 'O partidarismo no Brasil (2002/2010)', Opinião Pública, I7: 2 (201 I), pp. 400-25; David Samuels, 'A evolução do petismo (2002-2008)', Opinião Pública, I 4: 2 (2008), pp. 302-18; Gustavo Venturi, 'PT 30 anos: crescimento e mudanças na preferência partidária', Perseu, 5 (2010), pp. 197-214; André Singer, 'A segunda alma do Partido dos Trabalhadores', Novos Estudos Cebrap, 88 (2010), pp. 89-I I I.

${ }^{41}$ Perry Anderson, 'Lula's Brazil', London Review of Books, 33: 7 (201 I), pp. 3-I 2; Lincoln Secco, História do PT, 1978-2010 (Cotia: Editora Ateliê, 201 I); Hernán Gómez Bruera, Lula, the Workers' Party and the Governability Dilemma in Brazil (New York: Routledge, 2013); André Singer, Os sentidos do lulismo (São Paulo: Companhia das Letras, 2012). 
unequal economic structure, and he questions whether that combination will be sustainable in the long term. Secco, for his part, lays out a comprehensive and well-informed history of the PT from its foundation until 2010. Secco's account of the PT during the Lula governments gives a valuable picture of the countless dilemmas faced by the party and offers important data and information on the internal disputes that roiled the PT during its first years in the presidential palace. Bruera focuses even more squarely on the 'governability dilemma' faced by the party while holding the presidency. He claims that while cutting its teeth in subnational office, the PT evolved a 'social counter-hegemonic governability strategy' through which the party relied on civil society to implement its policies. Mobilisation was not simply an ideological desideratum or a bullet point in the PT's manifesto, but rather a political tactic to influence institutional outcomes. After winning federal power under Lula, however, the party shifted sharply towards an 'elite-centred governability strategy' that did not challenge traditional elites nor the institutional arrangements that have long favoured 'politics as usual'.

In a series of articles written and published between 2009 and $201 \mathrm{I}$, and subsequently compiled into a book, André Singer, a political scientist who served as spokesman and presidential press secretary from 2003 to 2007 , presents an interesting and influential interpretation of the PT's experience in federal power. ${ }^{42}$ Singer argues that the Lula administration was responsible for a political-ideological 'realignment' in Brazil. In Singer's view, in the Lula years the PT managed to synthesise the aspirations of a significant proportion of the Brazilian population (in his term, the sub-proletariat, comprised of the country's poorest citizens) to further a programme of poverty and inequality reduction without threating disorder. Singer also argues that the emerging socio-political matrix, which he refers to as lulismo, bears strong similarities to Roosevelt's New Deal. Both historical models were based on multiclass alliances advocating both economic expansion and robust social mobility, namely 'inclusive growth' in the current PT discourse.

Singer claims that a political-ideological realignment under Lula caused a noticeable shift in the profile of PT supporters, as discussed above. This bold hypothesis, however, is challenged by empirical studies such as those by Zucco, Rennó and Cabello, and Rennó and Peixoto. ${ }^{43}$ These scholars

42 Singer, Os sentidos do lulismo.

${ }^{43}$ Cesar Zucco Jr., 'The President's "New" Constituency: Lula and the Pragmatic Vote in Brazil's 2006 Presidential Elections', Journal of Latin American Studies, 40 (2008), pp. 29-49; 'When Payouts Pay Off: Conditional Cash Transfers and Voting Behavior in Brazil, 2002-2010', American Journal of Political Science, 57: 4 (2013), pp. 810-22; Lúcio Rennó and Andrea Cabello, 'As bases do lulismo: a volta do personalismo, realinhamento ideológico ou não alinhamento?', Revista Brasileira de Ciências Sociais, 25: 74 (2010), pp. 39-6o; Lúcio Rennó and Vítor Peixoto, 'Mobilidade ascendente e voto: as eleições presidenciais de 2010 no Brasil', Opinião Pública, 17: 2 (201 I), pp. 304-32. 
advance two alternative hypotheses. One is drawn from retrospective voting theory: citizens everywhere like good government, and a simple 'pocketbook voting' theory would predict that poor Brazilian voters in 2006 and 2010 would reward the redistributive successes of Lula. The second alternative hypothesis, stressed by Zucco, is that historically both poorer voters and poorer regions of Brazil (e.g. the north-east, the interior) tend to support incumbent executives, a phenomenon often referred to as governismo. Governismo is a rational political adaptation: it results simply from the dependence of poor constituencies on federal resources of all types.

These studies cast doubts on the grand realignment thesis proposed by Singer. The sceptics hold that we are not witnessing the construction of a new political-electoral dynamic, but rather a new conjuncture in which the PT benefits both from presidential incumbency and from positive views of its policy performance under Lula, views strongly held by the country's poor majority, if not by the traditional middle classes, in the elections of 2006 and 2010.

Yet as Zucco and Power observe, there is still no definitive verdict on the sustainability of lulismo. ${ }^{44}$ For such an evaluation to occur, it would necessary for the PT to abandon the presidential office. This could occur in one of two ways: either through the PT losing the presidential election outright (as happened in 1989 , 1994 and 1998 when Lula himself was the candidate) or by the party taking the unprecedented step of backing a non-PT presidential candidate from one of the other parties in the Lula-Dilma coalition family. The second option failed to materialise in the elections of 2014, when the Brazilian Socialist Party (PSB, historically a PT ally) withdrew from the governing coalition and ran its own candidate against Dilma. ${ }^{45}$ Even if this demand for power-sharing re-emerges in the future, it would be difficult for the PT to accept: of Brazil's ten largest political parties, only the PT and the PSDB have presented candidates in every presidential election since 1989. Lastly, we discuss recent papers by Samuels and Zucco and by Van Dyck. ${ }^{46}$ They represent newfound attention to the issue of how party organisation affects mass partisanship and electoral outcomes, an issue that concerned

${ }^{44}$ Cesar Zucco Jr. and Timothy J. Power, 'Bolsa Família and the Shifts in Lula's Electoral Base, 2002-2006: A Reply to Bohn', Latin American Research Review, 48: 2 (2013), pp. 3-24.

45 The PSB's original challenger was Eduardo Campos, a former Pernambuco governor who had served in Lula's first cabinet. After his death in a plane crash in August 2014, he was replaced as the PSB nominee by Marina Silva, a PT founder who was Lula's environment minister for five years and who quit the PT only in 2009. In the 2014 presidential runoff, the PSB endorsed Aécio Neves (PSDB) against Dilma Rousseff. The PSB thus moved from being a PT coalition partner to a strong oppositional stance in less than two years.

${ }^{46}$ David Samuels and Cesar Zucco, 'Crafting Mass Partisanship at the Grass Roots', British Journal of Political Science, first view article (2014), pp. I-2 I; Brandon Van Dyck, 'Why Party Organisation Still Matters: The Workers' Party in Northeastern Brazil', Latin American Politics and Society, 56:2 (2014), pp. 1-26. 
both Meneguello and Keck in their early works on the PT.47 Samuels and Zucco show that all parties in Brazil experience electoral gains after opening local branches on the ground (i.e. establishing a party directorate in a given municipality), but that only the PT has been able to cultivate authentic mass partisanship. According to the authors, the PT is able to attract new partisans only where civil society is 'dense' and the party is able to 'mobilise the organised'. Van Dyck, analysing the PT's strategy in the north-east, concludes that party organisation is still an important asset. According to him, the organisational expansion of the party in the region fostered its electoral gains in the north-east over the past decade.

\section{Lessons from the Literature}

In a famous passage from his Prison Notebooks, Gramsci observes that 'to write the history of a party means in fact to write the general history of a country from a monographic point of view'. ${ }^{48}$ Paraphrasing Gramsci, we might say that studies of the PT serve, albeit indirectly at times, as narrations and analyses of Brazilian politics in the current democratic period. Scholarly research on the PT sheds light on phenomena as varied as CSO resistance in the late I 970 s, the transition from an authoritarian to a democratic regime, the organisation of the party system, the process of political party institutionalisation, and the governing strategies used in post-1985 Brazil. Studies of the PT have also contributed to a broader cross-national literature that has emerged in response to the 'left turn' in Latin America, with progressive parties or leaders governing in Argentina, Bolivia, Chile, El Salvador, Ecuador, Nicaragua, Paraguay, Uruguay and Venezuela. Some comparative studies of the left turn have incorporated party organisation and development as variables that explain divergences in the types of leftist governments that have appeared in the region. In this section we will briefly discuss some of the analytical gains offered by studies of the PT with regard to both Brazilian politics and the recent leftward trajectory of Latin American politics.

Research on the PT has undeniably contributed to the sophistication of the academic analysis of the Brazilian political system, closely following a longstanding tradition in the European literature of examining the organisation, behaviour and transformation of political parties. As we noted in the previous section, theories and hypotheses originally articulated by Michels, Duverger, Kirchheimer, Panebianco, Katz and Mair have been applied to the case of the PT, broadening and deepening the debate over the organisation of political

${ }^{47}$ Meneguello, PT: a formação de um partido, 1979-1982; Keck, The Workers' Party and Democratization in Brazil.

48 Antonio Gramsci, Selections from the Prison Notebooks (New York: International Publishers, I97I), p. I 49. 
parties and the Brazilian party system. ${ }^{49}$ Another important gain has been methodological. Cumulative research on the party over the past 25 years has made more precise longitudinal studies possible, thanks to the data on organisation and electoral performance compiled by various scholars. Furthermore, the most ambitious monographs on the PT, beginning with the work of Meneguello and Keck, have benefited from consistent improvements in the collection and analysis of empirical data, setting a higher standard for the study of political parties in Brazil.

However, it is important to emphasise that researchers investigating the PT have an easier task than those who study other Brazilian parties. This is due to the ease with which empirical data on the party can be acquired. The Organisational Secretariat of the PT, for example, offers up-to-date and highly reliable information on party members and directories, spanning over 5,000 Brazilian municipalities. The party also maintains a detailed database on its internal electoral processes. Since 1996, the Perseu Abramo Foundation (FPA) has assisted the PT in systematising its documents and archives. The FPA, created by the party itself, also includes a Public Opinion Unit (Núcleo de Opinião Pública, NOP) that conducts opinion surveys of interest to the PT. Since I999, the NOP has used surveys to monitor the profile and opinions of party delegates who attend PT meetings and national congresses. This database has provided valuable primary source material for numerous empirical studies.

By highlighting the roles of unions and social movements in the formation of the PT, Meneguello and Keck reinforce characterisations of the period between 1978 and 1984 as a moment of intense social and political mobilisation in Brazil. In spite of the transactional nature of the transition from an authoritarian regime to democracy, ${ }^{\circ}$ actors from organised civil society emerged in that period with a series of political demands that were incorporated into the PT programme. In that sense, the first generation of studies of the PT painted a rich picture of how social movements and their participatory political practices represented yet another force pushing for

49 Robert Michels, Political Parties: A Sociological Study of the Oligarchical Tendencies of Modern Democracy (New York: Simon and Schuster, [ I 9 I I ] I 968); Duverger, Political Parties: Their Organisation and Activity in the Modern State; Otto Kirchheimer, 'The Transformation of the Western European Party Systems', in Joseph LaPalombara and Myron Weiner (eds.), Political Parties and Political Development (Princeton, NJ: Princeton University Press, 1966); Panebianco, 'Modelos de partido: organização e poder nos partidos políticos'; Katz and Mair, 'Changing Models of Party Organisation and Party Democracy: The Emergence of the Cartel Party'; 'The Cartel Party Thesis: A Restatement'.

so Donald Share and Scott Mainwaring, 'Transitions Through Transaction: Democratisation in Brazil and Spain', in Wayne Selcher (ed.), Political Liberalisation in Brazil (Boulder, CO: Westview Press, 1986.), pp. 175-215; Thomas Skidmore, 'Brazil's Slow Road to Redemocratisation', in Alfred Stepan (ed.), Democratising Brazil: Problems of Transition and Consolidation (New York: Oxford University Press, 1989). 
democratisation, and how relations between civil society and political parties evolved in the late I970s and early i 980 .

Since the studies described in Waves 3 and 4 were largely published after 2000, they are able to demonstrate how Brazilian politics in the post-Plano Real period (since 1994) has operated under a bifurcated dynamic of political competition: one that remains highly fragmented and pluripartisan in elections for the National Congress, while becoming effectively bipartisan at the presidential level. The PT has played a central role in this reorientation of electoral politics. On the centre-left of the political spectrum, the party has acted as one of two poles, the PSDB constituting the other, in presidential elections between 1994 and 20I4. Crucial to this process, as Hunter and Samuels argue, was the ideological moderation undergone by the party beginning in the second half of the I 990 os. ${ }^{\text {I }}$ Ribeiro and Amaral also identify the organisational force of the party, its territorial expansion, and the maintenance of ties with organised civil society, as important factors in the PT's arrival at such a prominent position on the Brazilian political stage..$^{52}$

Work on the PT has also contributed to debates that go beyond the delineation of the recent competitive dynamics of the Brazilian party system. Samuels and Samuels and Lucas argue that in terms of ideology and programmatic density the PT continues to be an anomaly in Brazil, which would mean the maintenance of the 'inchoate' system identified by scholars such as Mainwaring. 53 The staying power of that incoherence would represent a major obstacle to expanding the representative capacity of the Brazilian party system. Limongi and Cortez and Meneguello, however, argue that the party system is increasingly structured around the logic of presidential elections, and thus presents a growing degree of coherence. ${ }^{54}$ Braga, Ribeiro and Amaral suggest that the Brazilian party system has defied expectations and

5r Hunter, 'The Normalisation of an Anomaly: The Workers' Party in Brazil'; The Transformation of the Workers' Party in Brazil, 1989-2009. Samuels, 'A evolução do petismo (2002-2008)'.

52 Ribeiro, Dos sindicatos ao governo: a organização nacional do PT de 1980 a 2005; Amaral, 'Ainda conectado'.

53 Samuels, 'Brazilian Democracy in the PT Era'; David Samuels and Kevin Lucas, 'The Ideological "Coherence" of the Brazilian Party System, 1990-2009', Journal of Politics in Latin America, 2: 3 (2010), pp. 39-69; Scott Mainwaring, Rethinking Party Systems in the Third Wave of Democratization: The Case of Brazil (Stanford, CA: Stanford University Press, 1999).

54 Fernando Limongi and Rafael Cortez, 'As eleições de 2010 e o quadro partidário', Novos Estudos CEBRAP, 88 (2010), pp. 21-37; Rachel Meneguello, 'Las elecciones de 2010 y los rumbos del sistema de partidos brasileño: política nacional, fragmentación y lógica de coaliciones', in Manuel Alcántara Sáez and María Laura Tagina (eds.), América Latina: politica y elecciones del bicentenario (2009-2010) (Madrid: Centro de Estudios Políticos e Constitucionales, 201 I). 
undergone a gradual process of institutionalisation. ${ }^{55}$ However much they differ in their arguments, all these scholars agree that the PT has been a key player in the shaping of the Brazilian party system.

Work on the trajectory of the PT and of Lula's two governments (2003-10) has also been incorporated as a source of analysis for the recent literature on the 'left turn' in Latin America. The result has been the addition of a valuable comparative perspective to studies that tend to take a more limited look at the party and its path to the presidency. Among the many studies that examine the 'Pink Tide' in the region, we now draw attention to those that employ partylevel variables in explaining the different types of leftist governments that have emerged since the end of the 1990s. ${ }^{56}$

Lanzaro argues that the new leftist governments that have emerged in Latin America are novel principally because they represent what he calls 'Creole Social Democracy' in contradistinction to progressive governments that are populist or nationalist. ${ }^{57}$ The PT-led governments in Brazil (2003-), the Frente Amplio (FA) in Uruguay (2004-), and the coalition governments helmed by the Party for Democracy (PPD) and Socialist Party (PS) in Chile (2000-10, 2014-present) all fall in the Creole Social-Democratic category. For Lanzaro, the principal explanatory variable behind the emergence of this political phenomenon is the type of party that leads those administrations: parties of the institutionalised Left. The principal characteristics of this type of Latin American party are: (I) internal, determined by the high level of institutionalisation of party structures and practices and by the accumulation of political experience over time; and (2) external, characterised by integration into an electoral logic as a mechanism of political competition and by acceptance of the rules imposed by representative democracy. The PT, PS and FA acted, according to Lanzaro, as reformist governments that could be compared to social-democratic governments in Europe.

Levitsky and Roberts argue along similar lines and construct a typology of the leftist parties that have recently assumed power in Latin America, focusing on two dimensions: (I) the level of party institutionalisation and (2) the locus of political authority. ${ }^{8}$ With regard to the first dimension, there is a differentiation between consolidated parties with durable identities, rules and

ss Maria do Socorro Sousa Braga, Pedro Ribeiro and Oswaldo E. do Amaral, 'El sistema de partidos en Brasil: estabilidad e institucionalización (1982-2014)', in Flavia Freidenberg (ed.), Los sistemas de partidos en América Latina (1978-2014) (México DF: INE, forthcoming).

${ }^{56}$ A good overview of the literature on the 'left turn' in Latin America is found in Steven Levitsky and Kenneth Roberts (eds.), The Resurgence of the Latin American Left (Baltimore, MD: Johns Hopkins University Press, 20 I I).

57 Jorge Lanzaro, 'La social democracia criolla', Nueva Sociedad, 217 (2008), pp. 40-58; 'Uruguay: A Social Democratic Government in Latin America', in Steven Levitsky and Kenneth Roberts (eds.), The Resurgence of the Latin American Left (Baltimore, MD: Johns Hopkins University Press, $201 \mathrm{I}$ ).

${ }^{8}$ Levitsky and Roberts (eds.), The Resurgence of the Latin American Left. 
procedures, and new parties, which were created as electoral vehicles for leaders and social movements that emerged to challenge the political establishment in the late 1990 s and early 2000 s. As for the second dimension, the distinction is between parties that concentrate power in the hands of a single dominant personality and those that disperse power across the party organisation and among social movements. The combination of two dimensions produces four types of leftist administration: Institutionalised Partisan Left, Movement Left, Populist Machine Left, and Populist Left. It is interesting to note that Levitsky and Roberts divide the Institutionalised Party Left into two subtypes: electoralprofessional and mass-organic. Basing their analysis on the work of Hunter, Levitsky and Roberts locate the PT within the first subtype, along with the Chilean Socialist Party. 59

The literature on typologies of the Left and the effects of different party models on the performance of leftist governments in Latin America has benefited from the work on the PT discussed in the previous sections. The PT's respect for the rules of the democratic game, its construction of a centralised structure and clear mechanisms for resolving internal disputes, its ideological and programmatic moderation, its growing concern with electoral performance, and its adaptation of an institutional dynamic are all reasons why the literature on leftist governments in Latin America has described the PT as a moderate, institutionalised party that acts within the limits imposed by representative democracy. In that sense, when compared with other leftist groups in the region, the PT emerged over time as a party with clear social-democratic and anti-populist leanings.

\section{The PT in Perspective: An Agenda for Future Research}

This review essay has demonstrated that three decades of research on the PT has produced significant advances in our understanding of comparative party organisation, of Brazilian democracy, and of the evolution of the Left in Latin America. However, this does not mean that all debates are over nor even that all relevant questions have yet been explored. In this final section, we draw attention to three understudied aspects of the PT that, taken together, could profitably shape the next phase of research on the party.

The first research topic is that of ideology and ideational factors within the PT. Scholars of the PT, like the leaders of the party itself, have generally shied away from this issue. In the early years of research on the party, it was easy to distinguish the PT from its ideological competitors on the Left precisely because the PT was so emphatic in its rejection of these rivals. In the twilight of military rule, the nascent PT presented itself as an alternative to the historic

${ }^{59}$ Hunter, The Transformation of the Workers' Party in Brazil. 
Communist Party (PCB), to the populist Democratic Labour Party (PDT, a personalistic vehicle for the late Leonel Brizola), and of course to the pragmatic progressive wing of the PMDB (which would later form the nucleus of the PSDB in 1988). By contesting the three models represented by these groupings - Moscow-line bureaucratic socialism, Varguist corporatismpopulism, and moderate European-style social democracy, respectively, the PT essentially defined itself by what it was not. This negative self-definition gave the party a certain amount of space for experimentation: the PT could combine an external strategy of a vaguely defined 'democratic socialism' with an internal strategy of robust ideological pluralism. Fascinated by the PT's electoral advances and its striking creativity in subnational government, scholars paid less attention to the nuances of party ideology.

Yet two factors recommend more serious attention to ideology in the coming years. One is the obvious fact that the PT, as a whole, has moved closer to the political centre over the past decade: this has been corroborated by empirical research on legislative behaviour and on elite belief systems. ${ }^{60}$ Yet since this is also true of other left-of-centre parties in Brazil, it is necessary to determine whether the PT's centrist drift is system-driven or party-driven, or both. A second factor here is the persistence of latent factional conflict within the party. In the Lula-Dilma years, internal PT factions have typically been depicted as mobilising around two dimensions: economic orthodoxy (i.e. for or against the preservation of Cardoso's reform policies) and coalitional politics (i.e. whether to ally with traditional and clientelistic parties of the Centre and Right). While these have been fundamental axes of day-to-day politics since 2003 , they often overlay and obscure older cleavages about socialist alternatives that hark back to the PT's foundational debates in the 1980 s. To give a concrete example, the expulsion of PT federal legislators that led to the formation of the Party of Socialism and Liberty (PSOL) in 2004 was about more than just a one-off floor vote on social security reform: it was the result of long-simmering ideological debates within the party and the space for Trotskyites within a governing PT. ${ }^{61}$ The story of these debates has seldom been told, and when it has, it has been expressed largely in the alphabet soup of PT 'tendencies' (factions). Yet factions are merely organisational proxies for underlying ideational conflicts, and one of the unfortunate aspects of the governing Lula-Dilma years is that the substance of these conflicts has largely been overlooked. If and when the PT loses national power, the sources of two currently salient cleavages (responsibility for

${ }^{60}$ Timothy J. Power and Cesar Zucco Jr., 'Elite Preferences in a Consolidating Democracy: The Brazilian Legislative Surveys, 1990-2009', Latin American Politics and Society, 54: 4 (Winter 20I2), pp. I-27.

${ }^{61}$ Oswaldo E. do Amaral, 'Adaptação e resistência: o PT no Governo Lula entre 2003 e 2008', Revista Brasileira de Ciência Política, 4 (2010), pp. 105-34. 
macro-economic policy and decisions on coalition formation) may erode. At that moment, there is little doubt that older, underlying ideological tensions will resurface with a vengeance, and scholars of the party should prepare for the challenge.

Apart from ideology, another promising research topic in PT studies is the role of leadership within the party. Brazil's resurgence since the mid-r 990 is often attributed to above-average chief executives, especially Cardoso and Lula. Yet what is true for Brazil as a whole is even more true within the PT. Comparatively speaking, most distinct phases in party development are associated with sequential leaders: think of recent radical, reforming and centrist phases of the British Labour Party, which were presided over by Foot, Kinnock and Blair, respectively. Their equivalents in Brazil were, respectively, Lula, Lula and Lula. He managed to found a heterogeneous party, guide it through the turbulent I980s, strenuously resist the neoliberalism of Collor, and quietly manoeuvre the PT into the mainstream during the late Cardoso years, all the while suffering three defeats for the presidency and never losing control of the party (even fighting back a primary challenge from Senator Eduardo Suplicy in 2002). After eight successful years in the presidency $(2003-10)$, Lula's position in the party was so strong that he could single-handedly emplace the relatively unknown Dilma Rousseff as his party's candidate for president in $20 \mathrm{IO}$. This personal decision by the incumbent president (an outcome that would have been unthinkable only a few years earlier) was met by uncritical silence within a party long accustomed to vibrant internal democracy. Since Dilma's inauguration in $20 \mathrm{II}$, the relationship between the two PT presidents has been critical to the party's internal harmony as well as to its relationship to allies (with Lula serving as the informal guarantor of continued coalition government).

Future research on the PT could focus on some unanswered questions about leadership. First, what are the consequences of lulismo within the party and does Lula's long shadow strengthen the PT by increasing the value of the party label, or weaken it by downgrading the tradition of bottom-up, rankand-file governance? Second, especially given the economic downturn and protest movements since 2013 , what are the consequences of transferring the presidency to Dilma Rousseff, who lacks long-term roots and an identifiable base within the party? Third, given the overall importance of executive office to the recent successes of the PT, would it be possible for the PT to remain in a progressive coalition government while allowing an allied party to take over the presidency? For the PT, a party which has successfully bet on a presidentially-led strategy for many years, such a concession to a rival socialist party would be transformative.

This brings us to a third and final suggestion for future research on the PT: the party's relationship to the remainder of the Brazilian Left. Many casual 
students of Brazil and of the PT are surprised to learn that as recently as the early I 990 os, the PT was not even the largest party on the Brazilian Left: that role belonged to Leonel Brizola's PDT, which in the National Constituent Assembly (1987-8) controlled more than twice as many seats as the PT. Only in the presidential election of 1989 , when a late surge by Lula vaulted him slightly ahead of Brizola and into a runoff with Fernando Collor, did the PT begin to eclipse the PDT, and only after the I994 presidential election (when Brizola performed poorly) did the PT really emerge as the hegemonic progressive party. The PT has always enjoyed close cooperative relations with the Communist Party of Brazil (PC do B), which today is essentially a satellite of the PT, but its relations to other Left parties have been remarkably uneven. ${ }^{62}$ The PT has allied three times with the PSB, but has also been challenged three times by that same party (Ciro Gomes in 1998, Anthony Garotinho in 2002, and Eduardo Campos/Marina Silva in 2014). The PT also faced off against the now-minuscule PDT some three times as well (Leonel Brizola in 1989 and 1994, and Cristovam Buarque in 2006). Meanwhile, far-left factions in the PT have departed to form parties such as the PSTU (1993) and the PSOL (2004), while the PPS (heir to the old $\mathrm{PCB})$ has moved so far to the right that it is now a vociferous member of the PSDB-DEM opposition coalition in Congress. In the midst of all this, a small Green Party (PV) has also emerged, having mounted a strong presidential bid with Marina Silva in 20 ro.

Clearly, there has been a lot of change within the Brazilian Left, and almost all of it has been in response to the PT's impressive rise. Conversely, the PT's own posture towards other progressive parties is interesting in and of itself. In 1989, I994 and 1998, the PT allied only with other leftist parties, and lost every presidential bid; in 2002, 2006, 2010, and 2014 it allied with conservative and clientelistic parties, and won every time. This raises an additional question for scholars to explore: what lessons has the rest of the Brazilian Left taken from the PT's trajectory since 1989? This question remains unanswered largely because scholars have focused nearly all their energies on the PT to the exclusion of other leftist parties in Brazilian democracy. Yet the story of the esquerda brasileira writ large, that is, the broader progressive family of which the PT is a part, has not yet been told by any scholar since the transition to democracy in 1985 . Although there is much to praise in 35 years of research on the Partido dos Trabalhadores, a broader meta-analysis of the Brazilian Left is waiting to be written.

62 The PC do B is not to be confused with the old Moscow-line Brazilian Communist Party (PCB), from which it defected in 1962 during the Sino-Soviet split. The PC do B evolved from Maoism in the I960s to an Albanian line (Hoxhaism) in the I970s, and after the end of the Cold War it settled on a long-term strategic alliance with the PT. It is historically very influential within the National Union of Students (UNE). 


\section{Spanish and Portuguese abstracts}

Spanish abstract. Esta reseña examina críticamente la evolución de la literatura académica sobre el Partido dos Trabalhadores (PT) de Brasil desde su fundación en 1980. Organizamos la literatura relevante en cuatro fases: la fundación del PT, la experiencia temprana del partido en gobiernos subnacionales, su transformación y moderación a fines de los I $990 \mathrm{O}$ y, finalmente, sus experiencias en el gobierno nacional tras ganar la presidencia en 2002. Después de detallar las fortalezas y debilidades de todas estas líneas de investigación, también examinamos la trayectoria del PT a la luz de trabajos comparativos recientes sobre el llamado 'giro de la izquierda' en Latinoamérica. Concluimos ofreciendo una agenda para futuras investigaciones sobre el PT.

Spanish keywords: Brasil, PT, Partido de los Trabajadores, Lula

Portuguese abstract. Este artigo examina criticamente a evolução da literatura acadêmica sobre o Partido dos Trabalhadores (PT) do Brasil, desde sua fundação em I980. Dividimos temporalmente a literatura relevante em quatro fases, examinando a fundação do PT, as experiências iniciais do partido em governos estaduais e municipais, sua transformação e processo de moderação no fim dos anos I 990, e, finalmente, suas experiências no governo federal a partir da eleição presidencial de 2002 . Após detalhar pontos fortes e fracos deste corpo de pesquisa, examinamos também a trajetória do PT à luz de trabalhos comparativos recentes sobre a chamada 'virada à esquerda' na América Latina. Concluímos oferecendo uma agenda para pesquisas futuras sobre o PT.

Portuguese keywords: Brasil, PT, Partido dos Trabalhadores, Lula 